\title{
SELF-ANNULLING PRESTIGE FACTORS AMONG SPEAKERS OF A CREOLE LANGUAGE
}

\author{
WILLIAM J. SAMARIN
}

Hartford Seminary Foundation

Prestige in bilingual situations has been generally described as a unidirectional force. ${ }^{1}$ It is held that that language or form of language which contributes to one's social advance will dominate in any situation. Unfavored languages suffer by losing speakers to a prestige language and by borrowing features from it. Only in an insignificant way have prestige languages been known both as recipients and as donors, e.g. English, which has received some words from Amerindian languages as well as from immigrants to the United States.

The classic picture of such languages in contact is not entirely congruent with the relationship which Sango has to the vernacular languages of the Central African Republic. $^{2}$ There are two significant differences: (1) The direction of borrowing, triggered by the prestige value of the Sango language, is not always into the vernacular languages, although much of this occurs; rather, there is borrowing - better, pumping - into Sango. (2) The mechanism of borrowing is also different because of the absence of clear models.

This study describes what happens to a language which has an important prestige function when many of its speakers recognize that their mastery of it is incomplete. In this situation we expect to find people compensating for their ignorance by using words from their own languages. ${ }^{3}$ Such straightforward lexical borrowing we do in 1 Uriel Weinreich's technical definition of "prestige" as "the value of a language in social advance" is adopted in this paper $(1953,79)$. He rightfully rejects the use of "prestige" to cover such factors as usefulness, emotional significance, and literary-cultural worth. - Paul Friedrich critically read the earlier draft of this paper and made several suggestions about its organization which I gladly used and here acknowledge.

2 Recent treatments of Sango are Jacquot 1958, 1961a, b; Samarin 1955, 1963, 1964; and Taber, 1962a, b. For a complete bibliography, see Samarin 1955. - The term vernacular is used of all languages indigenous to the area except the lingua franca. (There is a vernacular "dialect cluster" consisting of Sango, Yakoma, and Ngbandi, which must be distinguished from the lingua franca. For the sake of convenience the term Ngbandi serves to identify the cluster.)

3 Some idea of the nature of the Sango lexicon is obtained from the following figures, based on the corpus used for Samarin 1963. The words identified as Sango include everything which is not French, even a few naturalized Portuguese and English words as well as those from other African languages.

$\begin{array}{lcrr} & \text { Types } & \text { Tokens } & \% \\ \text { Sango } & 489 & 33,989 & 91.3 \\ \text { French } & 508 & 2,518 & 6.8 \\ \text { Proper nouns } & & 710 & 1.9 \\ \text { Total } & \overline{997} & \overline{37,217} & \underline{100.0}\end{array}$


fact find, but what is more important theoretically is that borrowing is from another language or dialect. This is, moreover, something more complicated than needfulfilling borrowing, for many Sango speakers are found to reject a Sango word if they see that it is the same as their own vernacular one. Since some of these words are widely used, having the status of "standard" forms, the rejection of these words is interesting. This rejection-borrowing pattern turns out, in fact, to be triggered by a conscious adjustment of one's speech to an assumed prestige model of Sango. This, at least, is the theory suggested in this paper.

In the following sections the specific details of the study are presented, and two of its major implications for sociolinguistics are suggested. The abundance of factual data included in this paper is justified by the fact that they contribute to a better understanding of the problem and to the evaluation of the hypothesis here proposed. Since no such study has yet been published on a creole language, these data also serve to document the lexical diversity of one such language. ${ }^{4}$

\section{BACKGROUND}

The Sango language is the creolized lingua franca of the Central African Republic (formerly known as the territory of Oubangui-Chari of French Equatorial Africa). It merits being characterized as a creole language by the fact that it is a very much simplified form of a vernacular language of the same name, to which it has a relationship somewhat similar to that which Kingwana Swahili bears to vernacular Swahili. It is therefore of a different genre than creole languages such as Sierra Leone Krio (which is intimately related to English) and Haitian Creole (which is related to French), in that it is genetically fully African. It is a lingua franca, furthermore, because it is still used primarily as a second language by most of its speakers, although there is a growing number of children who are learning Sango either as a first language together with the tribal languages of their parents, or as a first language to the exclusion of any tribal language.

With about one million speakers, including those found in both Congo Republics, the Chad, and the Cameroun, Sango ranks among the important languages of Africa. This position does not result from any significant sponsorship by individuals or institutions for whom it had some particular purpose. The French government, in control until independence (August 13, 1960), made no systematic use of it whatsoever; administrators, nonetheless, were rewarded for learning Sango, as for any other vernacular language. There were few that did, however. Furthermore, no indigenous political party made use of it except when expediency demanded; that is, it never became one of the symbols for independence. Only the Christian missions, both

4 Taber, 1964a, b, attempts to correlate the incidence of French words with certain sociological factors. In general the incidence is lower in the speech of Central African elite than one would expect. 
Catholic and Protestant, have used it consistently and intensively. ${ }^{5}$ While it is true that the religious education of the missions probably introduced many people to Sango and perhaps contributed in some ways to their competence in using it, it would be foolish to credit the missions for the obvious increase in the use of Sango through the years.

Today, although French is constitutionally the only official language, Sango serves orally and in writing for the popular dissemination of communications of all kinds. ${ }^{6}$ Among government officials Sango is used along with French, although on the informal rather than the formal level. Although it has not yet been adopted by the government for use at any stage of public education, ${ }^{7}$ it is the only indigenous language to be used on the government-owned Radio Centrafrique.

5 There are differences, to be sure, between the degree of Catholic and Protestant use, and even between the use of three of the coöperating Protestant missions; but these differences are not relevant to our study.

- For example, the recent program to encourage and organize volunteer labor for national economic and social development, i.e. L'Organisation de l'Investissement Humain, has been given the name Kwa ti Kodro "village work", which is meant to translate Travail pour le Pays.

7 The following figures, which include all children enrolled in government-approved schools (but do not include a few score in specialized training), are important for giving an indication of the exposure which children have to the French language. Unlike the policy followed in many formerly Britishcontrolled areas, all instruction is officially in French. Teachers are not by any means averse to using Sango, however, and all of them are proficient in it. The school grounds, in fact, are where many village children, by their own admission, first learn Sango. These figures were obtained from an authoritative person in the employ of the Central African government. While they have to my knowledge never been published, they should be considered fairly reliable for the school year 1961-1962. The total population of the C.A.R. is given as being between $1,400,000$ and $1,700,000$.

(a) Certificat d'études (given on examination to terminate the education of those children who are not qualified to go on for secondary education): 1,272 passed out of 2,777 candidates.

(b) Examen d'entrer à sixième (given to determine the number who are qualified for secondary education):

1961: 390 passed out of 2,190 candidates

1962: 450 passed out of 4,000 candidates

(c) Number of children in primary and secondary schools, accurate only to within 500 because of a discrepancy my source was not able to resolve. The numbers in parentheses are to be read as ordinals, e.g. $(1)=$ first year of school:

(1) Cours préparatoire-1 29,000

(2) Cours préparatoire-2 $\quad 16,000$

(3) Cours élémentaire-1 , 11,500

(4) Cours élémentaire-2 7,300

(5) Cours moyen-1 6,000

(6) Cours moyen-2 5,000

(7) Collège, sixième année $\quad 900$

(8) Collège, cinquième année 530

(9) Collège, quatrième année 267

(10) Collège, troisième année 214

(11) Collège, deuxième année 68

(12) Collège, première année 50

(13) Collège, classe terminale $\quad 12$

(d) Premier baccalauréat: 12 Central Africans passed out of 37 (as compared with 10 out of 20 Europeans).

(e) Deuxième baccalauréat: 6 Central Africans out of 7 (as compared with 6 out of 7 Europeans). 
The importance of Sango in central Africa can be accounted for by two factors. The first is the existence of a large number of languages with no really dominant one among them. The second, which is the concern of this paper, is Sango's prestige value. For the thousands of men and women who are ignorant of the elite language, i.e. French, Sango is the only means for upward social mobility.

The Central African Republic, and probably the other areas where Sango is spoken, has a population which is classified in two ways. First, the inhabitants of Bangui, the Republic's capital, set themselves apart from all other people "in the bush" ("up country", etc.) who are known mockingly as ázò ti ngòndà "bush people". Within this sweeping characterization they include even the larger towns such as Mbaiki, Bambari, and Bossangoa, whose inhabitants number from 10 to 15 thousand people. In a similar but not so severe way, the town-dwellers consider themselves superior to the village-dwellers of the outlying districts. In both cases, we can speak of a superior urban group opposed to an inferior rural group.

In the second place, it is wealth and political power that mark off one class of people, comprised of government officials and other regularly employed but nonagrarian individuals, from the rest. This is the "upper class" at the top of a triangle which represents the total population; at the apex would be the elite class which is found in so many modern African societies. Below this upper class the population is not distinctly differentiated, and transition from one segment of society to another can be gauged only by amount of education and material prosperity. ${ }^{8}$ Accessibility to higher or lower groups in both directions is equally easy. That is, wealth and education do not themselves tend to act as consistent barriers between people, though of course they can be deliberately used as such. A more effective barrier to social intercourse is still geography. There is relatively little travel between the villages and the towns, and most of it is in the direction of the towns; town-dwellers are rarely seen in the villages. ${ }^{9}$

\section{DESCRIPTION OF TEST}

While in the Central African Republic two years ago to collect a linguistic corpus for a grammar project, I undertook two projects: a pilot sociolinguistic study, and one to test the degree of linguistic variability in the Sango language. The first study involved the use of a questionnaire, devised by myself, to determine such matters as age and sex of speakers, place and manner of the acquisition of Sango, and attitudes to the role

8 Some appreciation of the economic level of the C.A.R. is gained from the following facts. According to the Association Internationale de Développement (as reported in Le Moniteur Africain, Dakar, 25 Janvier 1964, p. 7) the gross national product in 1961 was 12 billion francs C.F.A. or about 49 million dollars. In this same year the average individual income was less than $\$ 30.00$. Among the 35 African nations for which there was information, the C.A.R. ranked 34th and 31st in these two categories.

- An indication of the limited travel to the capital is seen in the data on the informants. Of the 27, only 12 have ever been in Bangui, of whom again only 10 were there for more than a few weeks. 
and function of French, Sango, and vernacular languages. A third-year "collégien" assisted me by interviewing at random; my own use of the questionnaire was in studying a small Gbeya village in depth. ${ }^{10}$

It is not this proper sociolinguistic survey, however, which led to the formulations proposed in this paper. Data of sociological significance came from an unexpected source, i.e. the second survey mentioned above to test linguistic diversity. This included both a phonological and a lexical check-list, the purpose being to measure and describe the diversity observed in Sango. Since Sango is a second language for most of its speakers, the survey naturally revealed variations of the type that have led many to charge Sango with having practically no national homogeneity whatsoever. ${ }^{11}$

The lexical test consisted of asking informants for the Sango names of 24 food products, most of which were widely used in the Central African Republic. The test items were for the most part chosen at the open market in Bangui, the capital of the country. Grains and small dried fruits and leaves were preferred for convenience of handling; they were put in clear-glass pharmaceutical bottles about $2 \frac{1}{2}$ inches in height. A few fresh leaves were used under plastic covers until they became too discolored for easy identification. Food products were chosen for the test because this lexical domain was known to reveal considerable diversity. Precisely what items revealed the greatest diversity was not, however, known at the time. The selection might therefore be considered random with the qualification that I tried to make certain that only food items characteristic of the indigenous cuisine be included in the test: e.g. $k j k j$ (number 34 ) is never eaten by Europeans.

The interviews were conducted in the Sango language, by myself. Only one question

10 This study was done in connection with a six-week period of fieldwork undertaken in July and August of 1962. It gives me pleasure to acknowledge once again the assistance, financial and otherwise, of the following agencies who made my work possible: the American Council of Learned Societies, the Foreign Missionary Society of the Brethren Church, the Sango Grammar Project (with a grant from the Department of Health, Education, and Welfare through NDEA, Title VI), and missionaries too numerous to mention here. Previous to 1962 I was a resident of the country, at Bozoum, Mbaiki, and Bossangoa, for seven years. The questionnaire was drawn up after consulting the one used by Rubin, 1962.

11 The views expressed by a linguist are as unexpected as those by laymen are expected: Jacquot, after a two-month period of fieldwork, limited for the most part to Bangui, can claim (on what empirical basis?) that "Le sango n'est pas une langue homogène..." (1961b, 173). In an earlier report his statement was even stronger: "La diversité des influences subies par cette langue fait qu'elle n'a qu'une unité apparente et qu'il serait plus juste de parler de dialectes sango que de la langue sango" $(1959,5)$. No one can deny linguistic diversity in any speech community - even French, whether it be of France, Belgium, or Canada. It is the nature, degree and sociological correlates of this diversity that must be described. Remarkable homogeneity has been discovered in the language (Samarin, 1963); what differences there are - phonological and lexical - leave no room for its being reduced to an aggregate of "dialectes". Jacquot's observations may be criticized on several other points. For example, without having undertaken any extensive survey, he can yet say that "sa [Sango's] connaissance et sa pratique ne sont pas générales..." (1961b, 173). While the word "générale" gives little statistical information, its implication is clear enough. My own study of three remote villages in the Bozoum-Bossembele-Bossangoa areas (1962, not yet published) showed that Sango was so well known that almost all the women - Protestant, Catholic, traditionalist, young and old - had a fairly good knowledge of the language. 
was posed to the informant - and it was rare that it had to be repeated after he knew what was requested - sometimes in the form éré ti só nà yángá tí Sango yè "What's the name of this in the Sango language?" or mo dí éré tí só nà yángá tí Sango, mə̀ tènè $y \grave{e}$ "What do you call this in the Sango language?". Great precautions were taken at the beginning to distinguish between the Sango language ${ }^{12}$ and the informant's native language; but once he began to name the items, he was not interrupted, even if he obviously was mixing the two. Circumstances - like an unsolicited comment by a bystander - sometimes led, however, to obtaining both the Sango and vernacular forms for a single item. Otherwise, elicitation of the vernacular list followed the Sango one.

The interviews were without exception relaxed events. The informants did not give the impression of being tested. Since I had told them that I was studying the Sango language (mbì yi tí hingà yángá $t t$ Sango nzòni "I want to know the Sango lánguage well"), the informants behaved as if they were helping me.

\section{RESULTS OF TESTS}

The detailed results of the test are given in Appendix II. In this section I shall deal only with the data germane to my principal subject.

The most significant aspect of this study concerns a result which was not at all expected: namely, that several informants, in apparent ignorance of the common Sango words for some of the test items, used words from other dialects of their own languages or from completely different languages. ${ }^{13}$ Although such responses were few in number, in comparison with the general pattern to be discussed shortly (i.e. of Sango known, Sango unknown but vernacular known, Sango confused with vernacular, or item not known at all), they are striking. A theory must explain their occurrence, and

12 In this study the real etymology of a word is of consequence only because we are interested in determining the difference between vernacular and Sango words. The fact that a particular word is oRIGINALLY from Banda, Zande, etc., is in itself unimportant. Information concerning source of borrowing is, of course, valuable for other kinds of studies.

18 It is possible, of course, for me to say only that at the time of the interview a word was used, not INTRODUCED for the time in Sango. Except where an informant volunteered the information that he or other people used another word also, I can only assume that the word given was unique in his speech. This is not necessarily true, however, as any experienced field-worker will readily admit; only when an interview is carefully controlled, when data are abundant, and when possible errors are factored out, can one begin to feel confident of his data. Of one thing I am certain: in no case did an informant give the impression of having been induced into giving a word by the artificiality of the interviewing situation. Such spur-of-the-moment borrowings would obviously skew the data to the point of making my hypothesis extremely doubtful. It might have been valuable to have learned from the informants if they realized that they were using words from other dialects and languages. In an attempt to acquire some such information, I sent out in January 1964 a questionnaire with 42 words identified as Sango or vernacular by the informants I used in 1962. The 36 European correspondents were requested to interview Central Africans with the purpose of learning from them what they thought was the language source of each word in the list. Data obtained from 17 individuals in this way does not reveal any patterns of sufficient interest to warrant being reported here. 
this theory must take into account certain sociological factors, concerning both the country as a whole and the informants in particular. I account for these instances of borrowing by the relative prestige value of Sango as opposed to the vernacular languages. My hypothesis is that when a speaker is aware of several different words for certain objects or concepts, he will reject those that are most like the ones in his own language, being guided by the feeling that they are inferior to Sango. In some instances a word from his language may have been completely naturalized in the Sango language and be in general use throughout the country, but its identification with his vernacular is reason enough for him to reject it. Instances of this kind of borrowingrejecting pattern are given below under Corroborative Evidence. Before the data are presented, however, we need to see three other facts which emerged in the testing, none of which is unusual in a lingua-franca of this type.

1) The names of some test-items were unknown. This ignorance is correlated in part with inexperience with the world outside the local rural area. This would mean that an untraveled person would tend to know his own language's word for an item but not the Sango one, even though that item is well-known throughout the country. Even if he had occasion to buy some of these products at the town market nearest his home village, he would usually be buying from a person speaking his own language. ${ }^{14}$ The reason is that most of the towns are in areas where one language predominates. ${ }^{15}$

2) Several informants gave words from their own languages as Sango. This did not result from a memory lapse in every case; some informants insisted that the word they gave was both Sango and vernacular. Such borrowing is no different from the use of séti and mbásámbárá for "seven" by some speakers of Sango who do not know the French source for séti, which is clearly sept. The effect such lexical interference and borrowing has on Sango is obvious and needs no comment here.

3) A few test-items were not recognized at all; but apart from reducing the amount of information, this fact does not in any way skew the results.

14 One must understand that these markets are not at all comparable with those in much of West Africa. There, the market complex includes regular market-days and rather extensive travel to the market sites by sellers and buyers. In the C.A.R. the markets exist almost exclusively in the administrative centers, where the prefet or sous-préfet now resides, to provide food for the resident population and the transients.

15 The only population statistics available to me come from a report submitted to the Bureau d'Êtudes et Recherches du Plan, entitled "Mission Centre Oubangui: Recensement des Centres Urbains de la Kémo-Gribingui" (date unknown). It dealt in 43 pages (duplicated) with the towns of Fort Sibut, Fort Crampel, and Dekoa, as follows:

Fort Sibut: total population, 7,341. Banda: 46 percent; Manza: 46 percent (but this proportion of Manzas seems to be recent, because they comprise $70 \%$ of the total population who have arrived since 1950); Other: 8 percent.

Dekoa: total population, 3, 118. Manza: 69 percent; Banda: 20 percent; Other: 11 percent.

Fort Crampel: total population, 7,814. Manza: 64 percent; Banda: 22 percent; Other: 14 percent.

The tribal mixture in these towns may be higher than in many other areas, however, since (1) they are on one of the major roads which lead to the Chad, and (2) they are located in the area where two. principal groups, the Banda and Manza, meet. 


\section{INFORMANTS}

No difficulties were encountered in the selection of the informants. Since my principal activity was the recording of Sango speech with a tape-recorder, I had only to open my test-box to attract intense interest while I gave my (divided) attention to the recording. Long narrations gave me ample time to observe the audience and choose my informant. This was done with a deliberate plan in mind: it was important to the study to obtain maximum diversity, such as might approach the state attributed to Sango by uncritical observers. For this purpose I needed people whose experience with Sango was limited to a local variety. I imagined these to be either people who had never worked under polyglot situations (e.g. in the administrative centers, at commercial establishments, etc.) or those who had not traveled extensively. This would mean the young and the old, women rather than men, the unschooled, and the traditionalist rather than the Christianized. As it turned out, however, a few of my informants were quite sophisticated, although they did not represent the elite stratum in the society. Finally, I needed a good cross-section of the country, geographically as well as linguistically. These criteria were important, but their application at any place was influenced by circumstances beyond my control.

Among the several informants, two deserve special mention because their responses are typical of the general kind being described here. The other informants are more simply characterized in Appendix I.

Banda informant 15 is typical of the rural Central Africans who are consciously trying to identify themselves with the society and culture lying beyond the limits of their villages and kinship circles. He was uncomfortable with his backwardness, it seemed to me, and was eager to improve his position in life. Already in his early twenties, he had never gone to school and had never worked for a European, even though he had lived in Bangui for six months. He was quite explicit about the value of Sango, saying that parents taught their children Sango in the villages because without Sango one could not get jobs. He admitted that the Sango of Bangui was different, but that when he lived there, he used to ask people to help him improve his own Sango. For this young man, ignorant of French, Sango was clearly the only means for improving his station in life. This characterization finds clear corroboration by the young man's rejection of Banda words, even the widely-used ones, for words from other languages in his Sango.

The other informant (no. 27) also frequently adopts words from another language, but he is less of a model than the young man above. This is the Isungu chef de quartier at Berbarati, who claimed to have lived in that town for the last 30 years. Although an important figure in the Isungu community, he undoubtedly was a bilingual in the local Gbaya dialect. In any case, it is from this dialect that he draws his "Sango" words. The motives for doing so are not clearly the same as for the young man just discussed; if they are incontrovertibly different, he presents us with a case of language interference in a third language, i.e. from one's second instead of first language. 


\section{CORROBORATIVE EVIDENCE}

Of the 19 test-items which revealed lexical variation, 9 of them are characterized by the type of borrowing described above. They constitute in my opinion corroboration of the theory here being suggested. Test item 5 is discussed in some detail; the rest are treated in summary fashion. This item is an oily seed (Citrullus vulgaris Schrad.) which is widely used in the preparation of a common food. ${ }^{16}$ It was identified by no less than 7 different words, and 9 informants claimed that they did not know what its proper Sango name was (see Appendix II). But this information does not have the significance that the following does: consider the fact that there are three Banda informants (nos. 9, 15,16) and one Gbaya informant (18). Consider also the fact that two informants claimed not to know the Sango name for the grains and that the others used either a Banda word (mbákéré) or two words of undetermined origin (sérź, $k p l$ ). From these facts we might infer that the Banda speakers used the Banda word mbákéré, and that it was the Gbaya who could not identify its Sango name. Rather than this, however, we find that the Gbaya (18) informant was the one who used the Banda word; whereas two of the Banda ( 9 and 15) professed ignorance of the Sango name, offering the information that mbákéré was a word from their own language. The third Banda, however, attributed mbákéré to the Gbaya! He used only sérź and kpi for this grain. Presumably he would ascribe the presence of mbákéré in his own Banda dialect to borrowing from Sango. In this instance, therefore, we clearly see the rejection of forms from one's own vernacular, the adoption of forms from some other language, or the indecision about what are the authentic Sango forms. Of course, this was indecision only at the time of the test; in some contexts these speakers might very well use their Banda word while talking Sango; or having heard another word in another context they might use it, perhaps only for that occasion. The remaining eight test-items reveal the same kind of rejection-adoption pattern.

Item 3: Corroborative evidence is furnished by the word zùrù, which is widely used and commonly recognized as coming from the Banda language. Two sets of informants provide the data: (a) Isungu informant 27 used the word zùrù in his own language even while recognizing its source, but the word pon, from the local Gbaya, in Sango. (b) Of the eight Banda informants, only one, no. 20, used zùrù; the others used bondo, the etymology of which has not been traced. I assume that at least some of these seven informants have rejected their own vernacular zùrù, not realizing its wide usage; in the absence of their vernacular forms, the evidence remains assumptive.

Item 4: Three different informants provide corroborative evidence with respect to this uncultivated food item.

21 (Gbaya/Bogongo): ngálá < Gbaya/Berberati

26 (Gbaya/Yangere): ngiri < Banda

18 Italicized numbers refer to the test items; the other numbers refer to the informants. In this discussion words are identified by only one of their variants. The full range is indicated in Appendix II. The sign < indicates origin. Botanical identifications were made with a judicious use of Tisserant. 
27 (Isungu): ngálá < Gbaya/Berberati

It is extremely important that informant 26 uses a LOCAL Banda word; if he had used one from the east (e.g. ngiriki), we would have to admit that he had simply learned a generalized Sango word.

Item 6: The best corroboration is provided here by informants 13 and 21.

13 (Banda): sóngbá < Banda?

21 (Gbaya/Bogongo): sùndù < Gbaya/Berberati

The Banda informant's response is significant only when it is pointed out that she considered sindi (the common word for this grain) to be a Banda word, although it is not Banda at all and is probably the most common Sango word for sesame.

Item 8: Once again informants 13,15 , and 21 provide corroborating evidence.

13 (Banda): kákéré < Banda

15 (Banda): dàudả $<$ ?

21 (Gbaya/Bogongo): gón > Gbaya/Berberati

Both 13 and 15 are acquainted with kákéré and dàudá, but they use them differently: the first claims that dàudá is Arabic and the second that kákéré is his own vernacular.

Items 9 and 10: Isungu informant 27 again adopts the Gbaya/Berberati words. For 9, Banda informant 15's use of $k p i$ is possibly significant, because he rejects his own ksso which elsewhere is one of the proper terms for this seed.

Item 21: Banda informant 15 once again makes a significant switch. In spite of the fact that some form of the Banda vèkè is almost universally used in Sango (e.g. by 25 out of the 27 informants), this young man rejected it (though fully recognizing it as his own vernacular form) for dàrábà, which is unique in the study.

Item 22: In spite of the extreme diversity in the identification of these leaves, something of significance is to be found in the distribution of three vernacular words used by "outsiders" as Sango. (a) Gbanu informant 22 considered ngbúrú to be Sango, for she gave gbذ১r $\supset$ for her own vernacular; but Gbaya informant 3, interviewed at Bouca, gave ngbúlú, clearly the same word, as his own, and did not know the Sango. (b) Kaba informant 23 did the same thing, taking $b 3 l s$ from some as yet undetermined form of Gbaya speech, modifying it in the process (say, from gb33rj) or taking it in an already modified form. (c) The form búrúgùtú, used by Isungu informant 27, is obviously taken from a Gbaya dialect, for informants 21 and 26 give some form of gbúrúgbùtú as their vernacular.

\section{SOCIOLINGUISTIC IMPLICATIONS}

The phenomena which have been observed in the use of Sango by Central Africans are not without significance to our understanding of two subjects frequently mentioned in connection with sociolinguistic studies, namely, the role of prestige in language usage and the processes leading to language uniformity and diversity.

The conclusion that one must draw from these Sango data, sparse though they may be, is that a certain amount of lexical variation in Sango must be attributed to the 
opposition of prestige and non-prestige values in the society. Here, then, prestige works contrary to what one expects of it. Rather than being a force which leads people to UNIFORMITY in speech, it leads them to HETEROGENEITY. Wanting to speak proper Sango, people reject whatever they think is local; proper Sango is simply that form of the language which does not betray their origin. It is as if speakers sought for signs of emergence from the rural scene, since the village-dweller was considered as having nothing and knowing nothing; he was a non-entity.

\section{ROLE OF PRESTIGE}

The identification of prestige with the language itself is in negative terms. It is certainly not in terms of any particular dialect. While Central Africans can very often identify the ethnic or linguistic background of a person speaking Sango, they do not seem to recognize any other substantial patterned variations in the language. This is not from pride, nor out of defense for the universal integrity of the language, as seems to be true of speakers of Paraguayan Guaraní. ${ }^{17}$ The most characteristic attitude of Sango speakers is in fact one of tolerance. On several occasions when I have asked individuals about their evaluation of Sango speech which on linguistic grounds was definitely eccentric, whether spoken by Europeans or Africans, they have always expressed no cognizance of the differences but rather various degrees of surprise at my own observations. Excluded here, of course, is the speech of people still learning the language. Of them it would simply be said álà dè àhingà Sango kóe àpè "They don't yet know all of Sango"; this is meant as a simple statement of fact, not of attitude. ${ }^{18}$

By saying that language-linked prestige is negatively ascribed, I mean that that form of Sango which is least localizable is most acceptable. This appears to be as true for phonological aspects of the language (as when a Kaba uses $f$ for $p$ ) as for the lexical, although phonological differences seem to be better tolerated than are lexical ones.

It would be wrong, however, to interpret these statements as constituting a role of

17 Garvin and Mathiot 1960, 786. The Sango situation is also unlike the Jamaican one, where intolerance is articulated in terms of explicit evaluations. De Camp writes: "When I have suggested to informants lexical variants characteristic of another area, I have seldom noticed any reaction other than amusement at such absurd and outlandish words" $(1961,74)$.

18 It should be of some interest to note that I have never found an incipient Sango bilingual whose speech was halting or ungrammatical. Speakers may be embarrassed at speaking it (like adolescent Gbeya girls in the villages) or even deny any knowledge, but in every instance where speech duration was long enough for some observation (and I have a few tape-recordings), I found a typical Sango structure. Women are sometimes attributed a better knowledge of Sango than men, especially in Bangui. Jacquot reports: "Les hommes leur reconnaissent souvent une certaine supériorité dans la connaissance et la pratique du sango, car, disent-ils, elles sont beaucoup plus bavardes qu'eux" $(1961,174)$. This fanciful opinion hardly bears repeating as a source of information about language competence, although it can be regarded as linguistic pseudo-evidence for certain behavior. When analyzed, the Sango of women was no different from that of men (Samarin, 1963), but men have expressed their pleasure in the voice qualities of women's speech. It is smooth, oily, etc.: ànzèrè mingi "it is very sweet". 
evaluation used by the superior strata of society, for even here there is great tolerance. Recognized localisms are interpreted as deviations from the assumed norm only under certain conditions which have not yet been adequately studied.

But we are not so much concerned with potential confrontations of various forms of Sango as we are with the more powerful force of attitude in each Sango speaker. There is an abundance of NON-LINGUISTIC evidence, certainly, for believing that Central Africans want to lose their village identity. What this study has revealed is a peculiar type of LINGUISTIC evidence for this belief, namely, that the speaker in many instances will metaphorically grab at the closest available word, EXCEPT HIS OWN, when he wants to use proper Sango.

The Sango prestige configuration, while being idiosyncratic in some of its details, is not without parallel elsewhere. The most obvious one is the relation of non- or sub-standard idioms to standard languages. Here too speakers of the non-standard forms consciously seek to shed their localisms, leading to hypercorrections, a phenomenon which is documented with great skill in Dr. Labov's paper at this conference.

What is significant about the Sango case is that it validates an assumption made by Fischer in connection with language change. He suggests that "all societies possess some form of elite group - if only the 'ideal conformist' in some societies..." (1958, 53 , fn.). In the Central African Republic this group is clearly comprised of all those people who seek to shed their localisms. It is an "ideal" group because it has no geographical locality; it is still a model in the making.

\section{LINGUISTIC DIVERSITY}

While it is quite clear that the force of prestige is at work among speakers of Sango, it is not so clear that its linguistic effects are always those one might expect. Rather than standardization and uniformity, ${ }^{19}$ the data seem to indicate that it is increased variation which conformism leads to. In the absence of a clear model, a speaker's predisposition to conformism is inadequately realized; it is in fact irrealizable. It nonetheless produces a linguistic event which somehow satisfies the speaker's sensitivities. When speakers A and B each use the other's vernacular forms ( $b$ and $a$ respectively) for Sango, they obviously have not really measured up to the norm but only THINK they have. The result of such prestige-satisfying efforts results in variants $a, b, c, d \ldots n$ for any concept. (That the variants are in fact limited is immaterial here; we are not presently interested in a measure of the variability within Sango, but in its causes.)

The pattern just described can be illustrated by the following diagram, where arrows point away from the donor to the recipient languages. Proximity represents

19 For example, Lunt seems to suggest $(1959,23)$ that the strong tendency of Yugoslav villagers to adapt their own speech to fit the circumstances led to interdialects, nowhere defined, which constitute the base of Standard Macedonian. He writes, "I strongly suspect that the agreement [on what was acceptable Macedonian] stems in part from the existence of two or three 'interdialects', local koinés used in the larger market-centers by peasants from outlying villages. I was struck by the chameleonlike adaptation of the speech of unschooled villagers whose dialects I wanted to record..." 
degree of relatedness with the broken vertical line dividing the most remotely related or non-related languages:

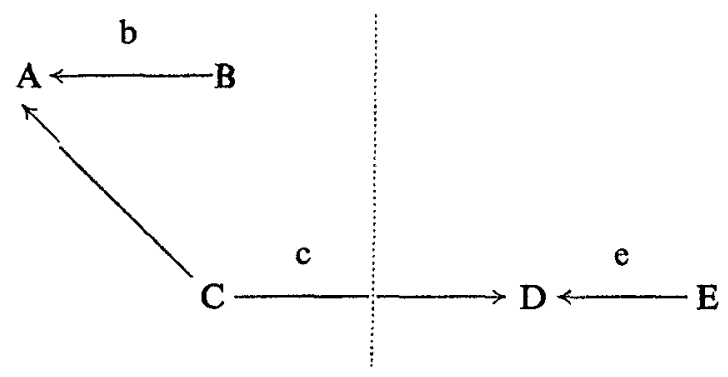

Thus, there are three donor languages, B, C, and E, giving rise to three different but synonymous words, $b, c$, and $e$. The diagram is incomplete because it does not show that some speakers of a language may borrow from another language which itself receives words from their own, e.g. A $\leftrightarrow$ C. Such is the case when a Banda speaker uses a Gbaya word and a Gbaya speaker uses a Banda word. Although my study does not show much evidence of this two-way borrowing for specific items, it can be assumed that it goes on for Sango in a general way. It can also be assumed that some languages or dialects, such as $\mathrm{A}$ and $\mathrm{D}$, are not so much donors as they are recipients. This fact would be represented by several numbered arrows directed from, say, $\mathbf{C}$ to D. To some degree this can be documented for Sango: more languages seem to receive FROM Banda than give To Banda. But it is possible that this is a flow which can only be looked at diachronically; there is less evidence for such flow today than there was in the past, when Banda men served in the French colonial militia.

It should be carefully noted that the preceding discussion deals only with the INTRODUCTION of new words into Sango, not of their spread. On the latter subject this essay has been discreetly silent. The distinction, of course, is a necessary one. Though a person may be strongly motivated to use a word from language $B$, this fact in itself is no guarantee that others will imitate him. The factors that may hinder or encourage the spread of an innovation will not be suggested in the present study, except for the observation that my theory assumes the rejection of some words by some individuals because of identification with words in their own languages. This rejection can be illustrated by the following diagram:

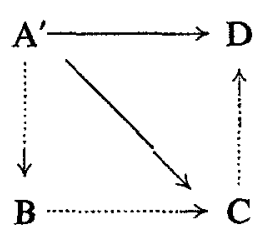

$A^{\prime \prime}$

That is, a word may be borrowed from $\mathrm{A}^{\prime}$, either directly (solid arrows) or indirectly (broken arrows) into $B, C, D$, but not into $A^{\prime \prime}$, the reason being that $A^{\prime}$ and $A^{\prime \prime}$ are 
dialects of the same language, or closely related languages, whose words for the object in question are identical. This word may be a very common one in the lingua franca because speakers of $B, C, D$, etc. use it; but since the speaker of $A^{\prime \prime}$ recognizes it as one of his own, he rejects it.

The process being postulated in this study is shattering to the lexicon - if one looks at it statically. It would be more accurate to use a dynamic metaphor and say that the process produces more lexical targets or models than are useful or necessary. It is for this reason that it is described in the title of this paper as "self-annulling": i.e., prestige perpetuates localisms rather than creating a standard form of the language.

It is difficult to ascertain the spread of the phenomenon described in this paper. Any parallel case would have to have two major characteristics: (1) a prestige model or ideal, if only negatively defined; and (2) speech diversity or indeterminacy which results from the response of speakers to the prestige ideal. A clear understanding of this second characteristic is needed to avoid making false analogies. It must be remembered that we are not concerned with all those individual cases of language "improvement" among people who are conscious of an inferior status, real or imagined. Closer to our study are instances when individuals choose to follow wrong models, leading, for example, to aren't I? instead of ain't I? and to you and I instead of to you and me. A whole speech community must show similar tendencies. ${ }^{20}$

Two such apparent cases are the following. The first involves idiolectal speech variation among rural Englishmen:

Anyone with direct knowledge of current English vernacular will know that dialect speakers are quite inconsistent in their pronunciation. So strong is the pressure of the standard language upon them, so willing are they to accept variant forms, and so ready are they to modify their own pronunciation in conversation not only with people outside their own intimate circle that their spoken words often occur in three or four different forms. (Orton, 1962, 18-19)

The second involves certain forms of extreme language urbanization. One of the best described cases is that of Town Bemba, a language of the "Copperbelt" of Northern Rhodesia. The language is a form of CiBemba which seems to have no uniform linguistic structure. It is not, in other words, a patterned dialect parallel in some way to vernacular Bemba. Rather it is characterized by "the somewhat negative tendency to indeterminacy in most departments of the language". ${ }^{21}$ More specifically, it "has no real homogeneity but is merely a complex of different ways of speaking an urban lingua

20 If analogical overcorrection, such as hyperurbanisms, could be shown to have skewed some linguistic patterns on a rather extensive scale, it would then be admittable here. But such cases are unlikely since analogy, by nature, works toward uniformity.

al Richardson 1963: 145. The implications of Town Bemba for the explanation of the origins of pidgin languages are not made by Richardson, but these are hardly avoidable. The theory most commonly held is that of inadequate learning: i.e. when a group of people inadequately learn a target language, the result is a pidginized form of it. (Considerable progress has recently been made in accounting for creoles such as English, Spanish, French, and others by tracing them to a widely used Pidgin Portuguese.) That this theory does not account for Sango has already been pointed out by me; that it does not account for Town Bemba is equally clear. Yet Town Bemba must certainly be considered a kind of pidgin language. 
franca based on Cibemba". Those statements account for the linguistic factors. The attitudinal factors are summarized in the following: "To a certain extent TB [Town Bemba] is a political symbol, a conscious reaction against the old way of life..." The prestige value of Town Bemba is clearly inferrable from that statement.

It would be surprising indeed to find that the phenomenon described in this paper has occurred only two or three times. Other languages marked by extensive lexical borrowing might upon further study prove to have been subjected to similar prestige forces. For the evidence to be valid, however, it will have to be shown that the lexical diversity did not simply result from prolonged exposure to other idioms. All languages can and do borrow - which is of course only a metaphoric way of saying that their SPEAKERS borrow - throughout their existence, but not all languages have to bear the stress and strain of man's will to improve his station in life.

It is for this reason that the history of Ashkenazic Yiddish is so intriguing (Herzog 1964). Though its lexicon is replete with words from Hebrew-Aramaic and from various German and Slavic dialects, it can not YET be shown that this mixture is due to strong prestige forces. While it is true that different dialects are characterized by having certain objects or notions represented by words from different languages or dialects, it is also true (and more interesting) that the words of a particular dialect for such pairs as button and to button up, to bless and blessing, to curse and cursing do not come from a single source as one might expect. For some reason not yet determined, the words of each pair have their own histories.

There is of course the strong possibility that the phenomenon we observe in Sango and Town Bemba is characteristic only of languages which have gone through a period of pidginization. Since several of these languages are still in existence and are, moreover, used in societies where language is an explicit status-ranking symbol, we should hope that investigators in the future will devote time to the search of similar prestigetriggered lexical diversity. Should they produce other such cases, we would have one more feature by which to characterize the creole languages - one which closely links sociological facts to linguistic ones. Having done this, our next step might not be entirely in vain: that is, the study of similar phenomena in the traditional "normal" languages.

\section{APPENDIX I: INFORMANTS}

The informants used for this survey are described below. The following abbreviations are used in the identification:

$\mathrm{gb}$ Gbaya-Manza language family

b Banda language family

s Sara language family

y Yakoma-Sango-Ngbandi language family

i Isungu (also known as Mbati)

f female

$\mathrm{m}$ male 
$r$ reads

w writes

/s Sango

/f French

P Protestant

RC Catholic

illit. illiterate

The entries, following the identification of sex, appear in the following order: native language' place of birth or long residence, literacy, religion, residence in Bangui (identified by the name of that city). The absence of an entry indicates that no information was obtained. Of the five language families represented above, all but Sara and Isungu are Adamawa-Eastern. Sara is Central Sudanic (of Chari-Nile) and Isungu is Benue-Congo (i.e. Bantu). Native languages are specified whenever possible by a "tribal" or geographical term, e.g. Gbaya/Berberati.

$1 \mathrm{gb}$ f, Manza, Bouca, rw/s, P.

$2 \mathrm{gb} f$, Manza, Bandoro, illit., $P$.

$3 \mathrm{gb} \mathrm{m}$, Gbeya, Doungbou, r/s, P, Bangui.

$4 \mathrm{gb} \mathrm{m}$, Manza, Bouca, $\mathrm{r} / \mathrm{s}, \mathrm{P}$.

$5 \mathrm{gb} \mathrm{m}$, Gbaya, Kamakota, r/s, P, Bangui (often).

$6 \mathrm{gb}$ f, Manza, Dekoa, r/s, Bangui.

$7 \mathrm{~b}$ m, Banda/Dakpa, Banguila, illit., Bangui.

$8 \mathrm{~b} \mathrm{~m}$, Banda, Ndele, $\mathrm{r} / \mathrm{s}$. Unmarried, young man, works in the mines at Bria.

$9 \mathrm{~b}$ m, Banda, Ouada, r/f, Bangui. Graduated from the Centre de Formation Professionnelle in Bangui around 1959. His Sango speech revealed much interference from Banda, e.g. the palatalization of /ti/ to [či.]

$10 \mathrm{~b} \mathrm{~m}$, Banda, Ippy, r/f. About 13 years of age.

$11 \mathrm{~s} \mathrm{~m}$, Sara-Madjingay, Nara (Chad Republic), r/s. Learned Sango after becoming a Christian, when he was already a married man.

12y m, Mbangi, Alindao, rw/s, $\mathrm{f}, \mathrm{P}$, Bangui. Had two years of elementary education in French. Worked at mission hospital from 1957-62. During this same period he served as an informant on the Sango Bible Translation Committee.

$13 \mathrm{~b} f$, Banda, Alindao, $\mathrm{rw} / \mathrm{f}, \mathrm{RC}$. This young girl was enrolled at the $\mathrm{RC}$ school at Ft. Sibut, Cours Moyen (first year).

$14 \mathrm{~b} \mathrm{~m}, \mathrm{Banda} /$ Djoto, Makorou, illit., RC. This middle-aged man had never worked for a white man. During the interview bystanders made fun of him for not knowing Sango well. Data obtained from him are not reliable because his Sango and vernacular lists are identical.

$15 \mathrm{~b}$ m, Banda/Djoto, Yatiganza, illit., Bangui (six months). A young man in early twenties who had never worked for a white man. He claimed to have learned Sango in the village.

$16 \mathrm{y}$ m, Yakoma, Kalimonga (near Ouango), rw/f, Bangui (seven months). Had seven years of education in French. Employed at Bambari as a gas-station attendant.

$17 \mathrm{gb} \mathrm{m}$, Manza, Dekoa, $\mathrm{r} / \mathrm{f}, \mathrm{s}$, Bangui (three years). Had four years of education in French.

$18 \mathrm{gb} \mathrm{m}$, Gbaya, Cameroun, Bangui (two weeks). Interviewed at Berberati.

$19 \mathrm{gb} \mathrm{m}$, Bogoto, Carnot. Had three years of education in French. Now employed as house-servant.

$20 \mathrm{~b} \mathrm{~m}$, Yangere, Berberati, $\mathrm{r} / \mathrm{s}, \mathrm{P}$. Has traveled a lot because of being employed as a truck-driver, but he has spent only a few days in Bangui.

$21 \mathrm{gb} \mathrm{m}$, Bogongo, Gbalondo (near Nola), Bangui (s al months). 
22gb f, Gbanu, Bounguinza. An older adult.

23s f, Kaba, sous-préfecture of Paoua, $r / s, P$. Had been in a multi-lingual environment for three years because her husband was a student at a Bible institute near Bozoum.

$24 \mathrm{gb} \mathrm{m}$, Gbeya, Bossangoa, r/s, P. Employed as a tailor's assistant in Bossangoa.

$25 \mathrm{gb} \mathrm{f}$, Gbanu, Bokoin, $\mathrm{r} / \mathrm{s}, \mathrm{P}$. The interview was done at Bossembele where she and her husband were attending a mission Bible school. She had never before resided outside her own village.

$26 \mathrm{gb} \mathrm{m}$, Gbaya/Yangere, Nagate (near Berberati). A young man whose manner indicated that he had not had much experience outside his own village. He did not seem to know Sango well.

$27 \mathrm{i}$, Isungu, Mbaiki. An elderly man, chief of the Isungu section of Berberati where he had lived for 30 years (or so he claimed).

\section{APPENDIX II: DESCRIPTION OF TEST-ITEMS}

Only the words given by informants as Sango are cited; their own vernacular forms are not listed here. The origin of the word, wherever known or strongly suspected, is enclosed in brackets []. Informants who used each term are identified by their numbers in parentheses. Also indicated are those informants who did not know the Sango name for the test-item or did not recognize it. Some items were not tested at all, either by oversight, misplacing of the item, etc.

2, dried corn kernels: gbànzà [?] $(2,3,5,8,14,18-22,24,26), n z o$ [?] (by all others). The closest parallel to either one of these words is gbonjo (Banda/Togbo) which Tisserant identifies as a white-grain corn "à épis longs et réguliers."

3, dried grains of mil (Sorghum guineense Stapf.): bondo [?] (1-9, 12, 13, 15-17, 24), pón [Gbaya] (21, 27), Sango unknown (25), not identified (26), zùrù [Banda] (by all others).

4, grains of an uncultivated tree (Beilschmidia ngriki A. Chev., "Arbre de galeries commun... La graine préparée est un condiment mucilagineux..."): ngéréké [Banda]

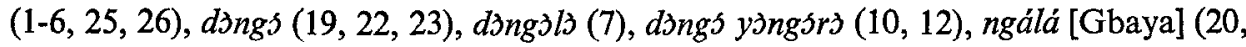
$21,27)$, piè [Banda] $(8,9,13-15)$, Sango unknown $(11,17,18,24)$. The words dings,

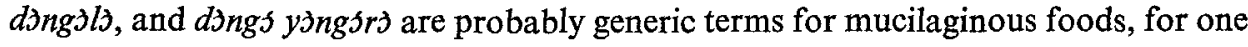
can use the expression ḋngs ḋngs even of slippery ground: cf. 21 and 22. According to Tisserant, piè is not the same as ngéréké, but Beilschmidia piya A. Chev. I have no way of determining now if the informants who used piè would distinguish between that and ngéréké, either in their own language or in Sango.

5 , oily seed (Citrullus vulgaris Schrad., cultivated for its edible seed): $k s s o$ [Banda?] $(20,21,25-27)$, kúkúrú [?] $(5,23)$, mbákéré [Banda] $(7,8,10,14,16,18)$, mbéréké [Gbaya] $(1,6,19,22,25)$, séré [?] $(13,16), k p i[?](16), b a ́ k p a ́$ [?]Sango unknown (2-4, 9, $11,15,17,24)$. Both $k j s o$ and $k p i$ are also used of 9 . Perhaps $k s s o$ is used by some people to refer to any edible oily seed. The word $k p i$ may also have some generic meaning, for it is also used of any oily edible paste, e.g. crushed sesame or peanut grains. The similarity between Gbaya mbéréké and Banda mbákéré (especially the variant form mbékélé) is 
striking; there seems to be a metathesis of the last two syllables. It is doubtful, however, that these are synchronic variants. The Gbaya form has typical variants in other

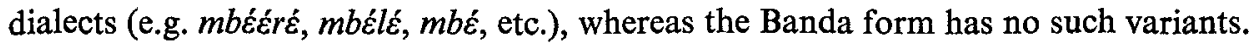
Besides, one is used predominantly by Gbayas and the other by Bandas.

6 , sesame seeds: núnú [Banda] $(2,4,11,14,22)$, sùnù [Gbaya] $(18,21)$, sindi [Yakoma?] $(1,3,5-10,12,15-17,19,20,23-27)$, sóngbá (13). Tisserant traces sóngbá to Nzakara by way of Banda, but informant 12 said that it was from Ngbandi. The words sùnù and sindi are very likely cognates; it is quite easy to explain the relationship between $u$ and $i$, and between $n$ and $n d$.

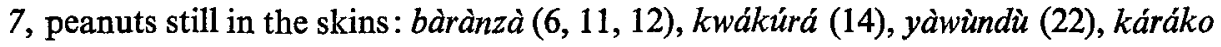
[Banda] (by all others). Bàrànzà is generally believed to be a Banda word, but Tisserant's only identification of bàrànzà is Hygrophyla longifolia Kurcz., which could hardly be mistaken for peanuts. Tisserant also gives the vernacular Sango as the origin of káráko, but Lekens does not have this word in his dictionary. Kwákúrá is probably related to the Banda word akora recorded by Tisserant for peanuts. The single informant who used yàwìndì was using the name of a specific type of peanut which goes by the name of the Cameroun city Yaounde.

8, grain of an uncultivated tree (Amblygonocarpus Schweinfurthii Harms. The pods are collected from the ground beneath the trees and broken up for the grains. These are used in the preparation of a sauce): daddàwá $(5,19,20,27)$, dàùdá (9), gsno [Gbaya] (21), Sango unknown $(3,4,18,22,25,26)$, kákéré [Banda] (by all others). The words dàdàwá and dàudá can not be traced with certainty; informant 5 claimed that dàdàwá was Boronu, and 13 that dàudá was Arabic.

9, oily seed (either Lagenaria vulgaris L. or Cucumeropsis Manii Nand.): kàndà (14), kpí (15, see comments for 5), mbéréké (3, 19, 27, see comments for 5), Sango unknown $(25,26), k s s o$ (by all others). Kàndà is not to be considered a significant variation, because of the undependability of the informant. The only kandà identified by Tisserant (for Banda/Togbo, Langwasi) is used of corn. Kosso is the most widely used term, apparently coming from Banda. It is this word which is identified with Lagenaria. The Cucumeropsis identification is based on the use by two informants $(26,27)$ of ngùmbe in their vernaculars.

10, edible wild fruit (Vitex sp.): birí [Gbaya] $(5,18,27)$, árí́ [Banda] $(8,13,14)$, gbigbi [?] (17), Sango unknown (1-4, 6, 7, 9-12, 15, 16, 19-26). Informant 21 did not name the item but identified it by calling it lé tí kéké tí ngòndà "fruit of a wild tree".

21, sun-dried okra pods (Hibiscus esculentus L.): dàrábà [?] (15), d’ngs (21, probably used in the generic sense, see 4), vèkè [Banda] (by all others).

22, edible leaf (botanical identification is uncertain. If this is mbùnù, it may be Ceratotheca sesamoides Endl.; but if it is gósá, then it may be Corchorus gen., cf. 31): gósá [Banda/Langwasi] $(1,2,19,24)$, mbùnù [Banda] $(6,8,13,14)$, búrúgùtú [Gbaya?] (27), ngbúrú [Gbaya] (22), vèkè (26, cf. 21), bj̀l [Gbaya?] (23) dàndó [Banda?] (14),

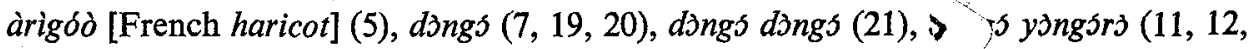
16), d’ngsrı̀ yjngsrò (15), Sango unknown $(3,4,9,18,25)$. Thi xtreme variation is 
probably indicative of a difficulty in the identification of the leaf. It is nonetheless strange that the common semantic feature in most of these words is the mucilaginous characteristic.

23, small red peppers (Capsicum annum L. or Capsicum fruticosum L.): mànzékè [?] $(3,4,14)$, ndóngó [?] (by all others). Tisserant is probably wrong in attributing mànzékè to Banda/Linda, since the first syllable mà- (as in other Sango words) can be attributed to some Bantu language, perhaps Lingala. Tisserant also attributes ndóngó to Ngbandi, but Lekens does not have this entry in his dictionary. In any case, the many different vernacular forms show enough similarity among themselves and with ndóngó that one is led to believe that the relationships are old. In other words, it may be impossible to distinguish a truly Sango word from a very similar vernacular word.

24, cola nut: gor̉ [?] (by all informants). The universal recognition of the cola nut and the unanimity of the appellation is surprising indeed, when one considers the fact that cola-chewing is not at all wide-spread among the indigenous population. This habit is found primarily among the West African traders, but also to some extent among the male inhabitants of the larger towns, especially Bangui.

27, wild pepper (Xylopia aethiopica A. Rich., sold in the markets to cola-chewers but widely known for its use in the preparation of food): màzindi [?] $(12,13,17)$, símbá [?] (23), nzángé [Isungu?] (27), Sango unknown (18-22, 24-26), not tested (1-11, 14-16). Tisserant attributes màzindi to Banda, but this is doubtful for the same reasons given for mànzékè above. Informant 20 simply described this fruit as ndóngó tí ngòndà, literally "pepper of bush", i.e. "wild pepper".

28, edible leaf (Solanum aethiopicum L.): pásá [Gbanu?] (22), njj̀njj [Gbaya] (19), Sango unknown (23), not tested (1-11, 14, 19-22, 27), ngágo [?] (by all others). Tisserant attributes ngágo to Banda, Gbaya, and Manza, but this is unlikely since other Gbaya words are known. It is probable that his informants gave him either the Banda word, in the case of Banda informants, or the Sango word, believing it was their own.

31, edible leaf (Corchorus gen., based on the informants' identification as gósá

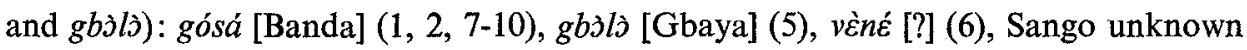
$(3,4)$, not tested (11-27). My notes indicate that, according to a Central African, vèné came from the Yakoma language; it is not found in Lekens' dictionary, however.

32, edible leaf (Hibiscus sabdariffa $L$., based on the informants' identification as kókpa and zimà): kàràkánzi [?] (5-7, 9), kókpa [Banda] $(8,10)$, Sango unknown (1-4), not tested (11-27).

33, edible leaf (Cucurbita Pepo L.): kàwàyà [Banda] (2-4, 7-10), Sango unknown $(1,6)$, not tested (11-27).

35, edible leaf (Amarantus caudatus L., based on informants' identification as lúmbú and mbúdé): gbùdù [?] $(1,2,4,5)$, lúmbú [Banda] $(9,10)$, ngágsá [Banda] (7), Sango unknown $(3,6,8)$, not tested (11-27). The ngágsá identification is probably an incorrect one, for it is a dialect variant of ngágo, cf. 28 . 


\section{DISCUSSION}

RICHARDSON: I would like to say that, although the parallel drawn by Dr. Samarin between Sango and Town Bemba in no way disagrees with the sense of my articles $(1961,1963,1964)$ on the linguistic effects of urbanization, the situation is of course rather different in the two areas. Town Bemba, as its name implies, flourishes in an entirely urban context. It is the mark of the urbanite, of the élite, of the people who have 'been places' and can go back home and tell the villagers what it is to live the life of the bright lights.

Moreover, there are quite definitely some political overtones in this language. These emerge partly from factors attaching to a particular situation. The Bemba tribe lives in Northern Rhodesia. Bemba is a Bantu language and one of the six major vernaculars taught there in the schools. There are of course many other 'minor' languages. The Bemba have exhibited a remarkable degree of cohesion and also a spirit of opposition to colonialism. This is true of other tribes - but the Bemba have been very articulate about it. They have bred many politicians, trades-union leaders and businessmen. These form, in a sense, the spearhead of the attack. Many of the negotiations on political and trades-union matters are conducted in Bemba. I would not claim, however, that the language used in these instances is Town Bemba. Indeed its affiliations are rather with 'classical' or VILLAGE Bemba. Nevertheless, it is because of the feeling that Bemba is the language of those who seek to overthrow the old régime that a deviant version has been adopted in towns.

There is also a demographic factor favoring the adoption of Bemba in the Copperbelt. Most of the migrant labourers are of Bemba origin. However, even given the political and demographic reasons for the rise of a deviant version of Bemba as an urban lingua franca, it is still hard to see why one of the most complicated languages in Bantu Africa should have been chosen for this role. Apart from exhibiting an 18-class grammatical structure - which is typical of many languages of this region it also has more than 30 one-word affirmative tenses and over 20 corresponding negative forms. In addition to this there are several compound forms which occur through a large part of the tense range. The usage of the correct form is determined, not only by time- and aspect-reference, but also by various syntactic criteria. Often the distinctiveness of several forms depends entirely on vowel length or tonal phenomena.

It is only when one considers the alternatives to Bemba that it becomes obvious that social rather than linguistic motives dictated the choice. Other tribal languages failed to appeal to the town-dweller because they had little or no prestige in an urban context. The only serious challenger was Nyanja - but this bore the taint of having been set up as the medium of communication in the Army and in the police forcethe 'institutions of oppression'. Consequently, despite the fact that it is far more amenable to the foreign learner than is Bemba, its influence is rapidly declining. Cikabanga, a derivation of Kitchen Kaffir from South Africa, is a kind of pidginized 
language with a vocabulary largely composed of Southern Bantu, Afrikaans and English words. It is no one's mother-tongue but is used as a 'work language'. Many people of European origin in Southern Africa consider it to be the ONLY suitable language in which to address a Bantu-speaking African. Thus, Cikabanga has acquired the reputation of being a 'master-to-slave' jargon which is totally unacceptable to the emancipated townsman. The only other possible choice was English. English enjoys the greatest prestige of all the languages in the Copperbelt, but owing to inadequate educational facilities, there are comparatively few who speak it well, and so a variant of Bemba was chosen as the most practical and prestige-conferring solution.

At this point I feel that I should indicate that while a knowledge of either English or Town Bemba confers great prestige on the speaker, the difference in prestige afforded by these two languages is one of character rather than of degree. In other words, a fluent speaker of English creates for himself an image of being not only a scholar but also one of the intelligentsia to whom eventually no door will remain closed, whereas the ability to speak Town Bemba shows to one's fellows that the speaker has made the necessary adjustment between the old and the new with equanimity and even with a certain panache.

It has already been pointed out that both Sango and Town Bemba lack homogeneity. It is probably truer to say that Town Bemba is an all-embracing term for the general corpus of speech produced by Africans of varying linguistic and social backgrounds in their attempt to reach the 'ideal' standard of Town Bemba. From statements gathered in the field, it appears that this 'ideal' really exists in the minds of towndwellers and could briefly be defined as 'the type of Bemba spoken in towns by those who have Bemba as their mother-tongue'. This is not to say that this 'ideal' is identical with Village Bemba. Indeed, even the EXPERT speakers of Town Bemba deviate to a limited degree from village usage, as for example in the re-assignment of certain words to different grammatical classes. The chief differences, however, lie in the lexicon and in the style. Town Bemba prefers the imported word to the local product. Furthermore, when traditional words are used it is often with so violent a semantic 'twist' that traditionalists fail to understand them. The style of speech must be racy, allusive, and amusing. New terms are born and die with bewildering rapidity, but the really proficient speaker must keep abreast of the times, thereby proving to others that he is an initiate of the inner urban circle and that THEY are still emerging from the dark ages.

In conclusion, it should be noted that many of the features I have described are not specifically African but can probably be paralleled in any society where certain elements feel the need of a linguistic 'uniform' to rally them against the others.

P. Ivić: It seems to me that the nature of the instability and diversification in Sango and in Town Bemba is not the same. In Sango we have to do with a kind of hyper-correction. Speakers of dialect A think that elements of Sango, which are identical with their own language, really do not belong to Sango. Therefore, they use the 
form of dialect $B$, and vice versa. In Town Bemba we have to do with a breakdown of the grammatical pattern. The contact and interference between a number of dialects with very complex and very different structures leads inevitably to an abolition of many existing distinctions - of course not in the same way throughout the whole area.

GaRvin: Thanks to the presentation by Dr. Samarin, I have an idea for summing up what one deals with in sociolinguistics. There are two clearly defined language situations that can be treated only in terms of this hyphenated discipline. One is the standard language problem; this is linked, to some extent, to the question of language and dialects as defined in a social sense, rather than by the Bloomfieldian criterion of intelligibility. The second is the question of lingua franca, which was raised in the Sango situation. My own work has been in the area of standard language more than that of lingua franca, so I am tempted to use some of the standard language criteria, apply them to the Sango situation, and point out the differences. One salient point is that there seems to be no codification in this Sango language, which means that its speakers form their notions of the language in terms of their own folk-linguistics. They apparently have a sort of folklore about what Sango ought to be like, and there is no code for them to use as a frame of reference. It seems that the overriding function here is the prestige function, while the others, the separatist and unifying functions, are less significant. And the prestige function is apparently assigned to something that is not the vernacular. Consequently the folk-linguistic conception of the speakers apparently is defined entirely by contrast, which gives you des entités négatives et oppositives in the Saussurean sense, in a somewhat extreme form. This seems to me not to be the case of the usual pidgin, which is not interpreted negatively, but in some sense positively.

HAUGEN: I had the opportunity of reading part of a thesis which has been worked out under Dr. Samarin, and I noticed one point which seems to me to have some interest. I think there is a good deal to be said for the point of view that this is not a language. According to the thesis, the whole language, as analyzed from over 37,000 words of running text, has only 482 words.

SAMARIN: Less, actually, because we put words into the index that we, as speakers of the language, had discovered elsewhere. So there were less than 482 in the corpus.

HAUgen: This comes awfully close to that old fable about the language in Africa that had only 600 words. And this may be the place where that came from! The story has been rejected by competent linguists for so long that I hesitate to accept this as a language until this particular point is cleared up. The texts that you collected seem to be largely loan words strung together by a small number of function words. Now this can conceivably be a language, but some of the things that Paul Garvin mentioned about standardization are certainly applicable here. We may have a koiné or a pidgin in the making. However, your mode of deriving the data here may have influenced this particular problem to some extent. I would like to know how the vocabulary of this idiom compares with that of the vernaculars. Is it as much smaller as this seems to make it, on the assumption that the vernaculars have a normal size vocabulary (whatever that is)? As for the negative influence, $I$ think is certainly 
present in every standard language and koiné, because people learning a standard language are afraid to be using the words that are natural to them. So they avoid them and adopt entirely different words. In this way a kind of consensus is gradually arrived at, and I don't think the codification is necessary at all. A formal codification is an entirely secondary thing. Informal codification comes into being among the speakers as the result of a consensus and of some kind of prestige nucleus among the speakers, which apparently is not present here. French is the prestige language, and whether Sango is a prestige language is a matter of debate.

Samarin: Sango does have, as we see in the texts, very few words. And many of the French words could be eliminated without hampering the language at all. Some of these are just synonyms. For example, the French word mais is used in Sango, with no distinction from $n a$ "but". In fact, they say $m \varepsilon n a$. Of course, other words like commander are used, and there are no Sango equivalents. But Sango is not French interlarded with African words. Most of the French borrowings are nouns; there are very few borrowed function words, and in a single text, especially a conversation or a fable, there is a very low frequency of French words. In our 37,000 word corpus there are 508 French words. But all I can say is that it is a language, because I can spend hours with my friends talking about all kinds of things, describing Los Angeles and how many cars are on the streets, and so on. But we do have some difficulty talking about theology. The whole Bible has been translated, though sometimes with great difficulty, and of course it is not like an English translation (see fn. 3).

FERGUSON: The kind of negative selection found in Sango occurs very commonly, although in a minor way perhaps, in a diglossia situation. If the so-called 'high' variety in a diglossia situation has two alternative ways of saying something, and one of them happens to be like the local dialect, a speaker will normally reject the one that's like his local dialect when he writes or uses the higher form of the language. In the last 100 years, this has actually pushed some words almost completely out of Classical Arabic. For example, you used to be able to say rāh or $\partial a h a b$ as the verb "to go" in Classical Arabic. Bur răh is the normal word in many dialects, and people don't want to use that in written Arabic. So now written Arabic uses $\partial a h a b$ almost exclusively as the verb "to go". This happens not only in lexical items but even in grammatical features. There are two ways of making the negative of the past in Classical Arabic. One of these ways is very much like the way that is used in many local dialects, so that way is used much less now than it was in older texts. This kind of negative selection, I think, occurs not only in Arabic but in languages like Swiss German, Haitian Creole, and so forth.

LABOV: It might be useful to compare a diagram of the New York City situation with the sociolinguistic situation that Dr. Samarin has just described. This is a threedimensional sketch of the in-gliding vowel system in New York City. (See diagram.) At the top is the plane of casual speech, the vernacular as used by the younger generation of New Yorkers. There are three phonemes: /ih/,/uh/ and /ah/. This is the system which reveals the dynamics of linguistic interaction in phonological 


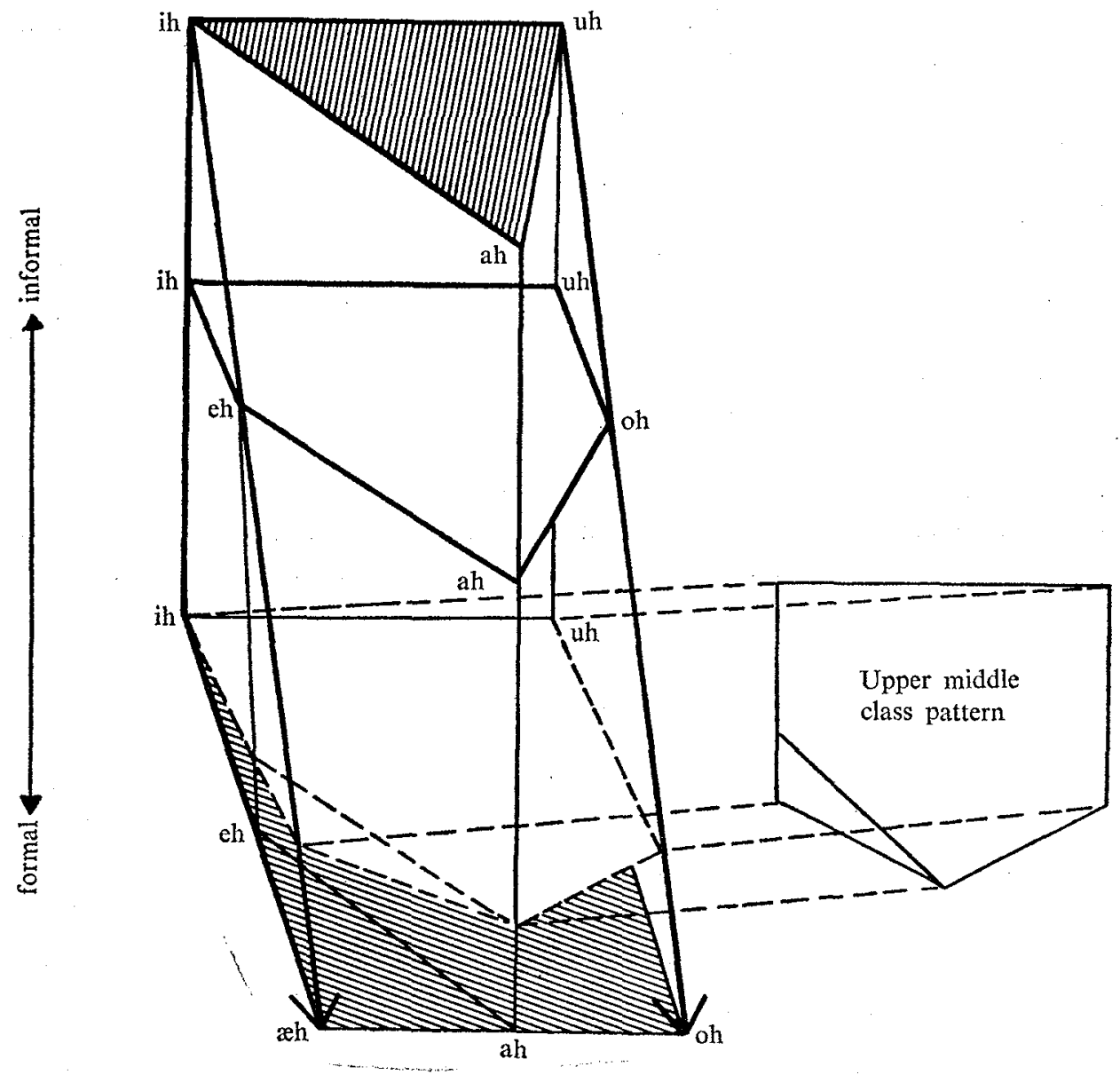

space as described by Martinet and by Moulton. At the bottom is the plane of the most formal style, the type of response given when you ask for isolated words as in Style D of our interview and the elicitation method of Dr. Samarin. Here we have six phonemes: /ih/ in here, /eh/ in there, / $\mathrm{eh} /$ in bad, /uh/ in sure, /oh/ in sure, /ah/ in bar and guard. This is hardly a coherent system: /æh/ and /oh/ fluctuate from short vowels to long, appearing and disappearing, and the system as a whole appears and disappears as the subject uses more or less $r$-pronunciation. It would be difficult to describe this plane as a linguistic system. The structural elements which are most consistent for the diagram as a whole are the upper plane of casual speech, and the direction of shift downward. This shift is governed by the prestige pattern, shown at the left. The hyper-correction, similar to that referred to by Professor Ivić, is shown by the fact that the end product of the stylistic shift goes beyond the prestige model. New Yorkers aim at this model but go past it. There is a striking parallel with 
Dr. Samarin's model in that there is little agreement, little uniformity, and little coherence in the elements of the most formal system.

STOCKWELL: Could you clarify this further with examples?

LABOV: Well, the three elements on the left of the bottom plane represent the word classes of here, there, and bad. In the most casual speech of most younger New Yorkers, the same phoneme is used in all three. So you have the same vowel in "I shaved my [br: $\left.{ }^{\circ d}\right]$, I cut my [hr: $\left.{ }^{\circ}\right]$, I had a [br: $\left.{ }^{\circ d}\right]$ cut", or "I shaved my [br:Td], I cut my [hr:T], I had a [br:Td] cut." It's hard for you to hear them as the same, because your morphological interpretation gets in the way. To give one actual example, one informant talked about giving her little girl a $\left[\mathrm{hr}^{\mathrm{o}}\right.$-cut. No one misunderstands her,

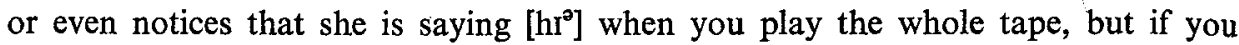
cut off the word cut, the listener hears the first word as here. In other words, here is only one front vowel, one low vowel, one back vowel, and an occasional center vowel in her and were. This describes the speech of large numbers of younger New Yorkers, under 40 years old, in casual style where pre-consonantal and final [r] does not occur.

\section{REFERENCES}

De Camp, David, "Social and geographical factors in Jamaican dialects", Proceedings of the Conference on Creole Languages (= Creole Language Studies II, ed. by R. B. LePage) (London and New York, 1961), pp. 61-84.

Fischer, John L., "Social influences on the choice of a linguistic variant", Word, 14 (1958), 47-56.

Garvin, Paul L., and Madeleine Mathiot, "The urbanization of the Guarani language, a problem in language and culture", Men and Cultures, Selected Papers from the Fifth International Congress of Anthropological and Ethnological Sciences, ed. by Anthony F. C. Wallace (Philadelphia, 1960), pp. 783-790.

Herzog, Marvin I., "Etymology versus geography: a study in Yiddish lexical differentiation". Paper read at the Linguistic Circle of New York, March 14, 1964.

Jacquot, André, "Enquêtes socio-linguistiques concernant la langue sango", Bangui : IEC/ORSTROM, Octobre-Décembre 1958 (1959).

_- "Notes sur la situation du sango à Bangui, résultat d'un sondage", Africa, 31 (1961), 158-66. (a)

__-, "Esquisse phonologique du sango urbain (Bangui)", Journal de la Société des Africanistes, 30 (1961), 173-191. (b)

Lunt, Horace G., "The creation of standard Macedonian: some facts and attitudes", Anthropological Linguistics, 5:1 (1959), 19-25.

Orton, Harold, Survey of English Dialects, A: Introduction (Leeds, 1962).

Richardson, Irvine, "Some observations on the status of Town Bemba in Northern Rhodesia", African Language Studies, 2 (1961), 25-36.

—, "Examples of deviation and innovation in Bemba", African Language Studies, 4 (1963), 138-45.

- "Linguistic change in Africa with specific reference to the Bemba-speaking area of Northern Rhodesia", Symposium on Multilingualism, Brazzaville, 1962 (London, Scientific Council for Africa, Publications Bureau, 1964), pp. 189-96.

Rubin, Joan, "Bilingualism in Paraguay", Anthropological Linguistics, 4:1 (1962), 52-58.

Samarin, William J., "Sango, an African lingua franca", Word, 11 (1955), 254-67.

-, A Grammar of Sango (Hartford, Conn., Hartford Seminary Foundation, 1963) (under a contract with the U.S. Office of Education).

- "Une lingua franca centrafricaine", Symposium on Multilingualism, Brazzaville, 1962 (London, 1964), pp. 257-65. 
Taber, Charles R., French Loan-Words in Sango: a Statistical Study of Incidence (Hartford, Conn., Hartford Seminary Foundation, 1964). To appear in Hartford Studies in Linguistics. (a)

"French loan-words in Sango: the motivation of lexical borrowing". Paper read at the Southern New England Linguistic Conference, Hartford, November, 1964. (b)

Tisserant, Charles, Catalogue de la Flore de l'Oubangi-Chari (= Mémoire de l'Institut d'Etudes Centrafricaines, no. 2) (Toulouse, P. Julia, 1950).

Weinreich, Uriel, Languages in Contact (New York, Linguistic Circle of New York, 1953). 